\title{
BACTERIOLOGICAL EVALUATION OF WOUNDS IN SERIOUSLY BURNED HOSPITALIZED PATIENTS.
}

\author{
Sueli de Lourdes Nogueira Vilela Silva, Oswaldo Gontijo Macedo, Carlos \\ Américo Veiga Damasceno, Maria Auxiliadora Roque de Carvalho and \\ Eduardo Osório Cisalpino.
}

\begin{abstract}
During the period between May and December 1988, 21 patients were studied bacteriologically at Hospital João XXIII's burn's unit which belongs to "Fundação Hospitalar do Estado de Minas Gerais" in Belo Horizonte, Brazil. A qualitative and quantitative evaluation of aerobic and facultative bacteria from burn wounds was carried out by the standard filter paper dise technique, including antibiotic susceptibility. At the same time an evaluation of those bacteria isolated from the environmental unit was performed. The most common organisms recovered from wounds of patients were: Pseudomonas aeruginosa, Staphylococcus aureus, and Staphylococcus epidermidis. P. pseudomallei was the most frequent strain recovered from environmental specimens. In nearly all patients specimens (16 in total) from whom $P$. aeruginosa was isolated, the rate of CFU/ $\mathrm{cm}^{2}$ of skin was above $10^{2}$. In nine of these, it reached $10^{5}$, wich is equivalent to $10^{7} \mathrm{CFU} / \mathrm{g}$ of burned tissue.
\end{abstract}

Key-words: Nosocomial infection. Burn wounds infection.

According to Sucena ${ }^{24}$ in 1982 , in the United States of America, two million cases of burns are registered per year, 200,000 of which require hospitalization, with a mortality of 12,000 . In Brazil, (where statistics are very poor), Russo ${ }^{22}$ registered a total of 871,692 labor accidents in São Paulo (in 1975), 27,894 of which were burned patients. Twenty percent of these (6.189) had to be hospitalized. It was estimated that hospitalization of these burned patients led to 836,820 lost working days. Nosocomial infections have probably been more prevalent following major burns than is any other condition in medicine. According to the information available, infection has been the leading cause of death in

\footnotetext{
From the Department of Microbiology, Institute of Biological Sciences, Federal University of Minas Gerais, Bèlo Horizonte, MG, Brazil.

Financial Support of CAPES, CNPq, PRPq/UFMG, FINEP.

Address for reprints: Dra. Maria Auxiliadora R. Carvalho, Department of Microbiology, ICB/UFMG Campus Pampulha, 30161 Belo Horizonte, MG, Brazil. Recebido para publicação em 20/03/91.
}

this type of injury ${ }^{611}$. As burn wounds are invariably contaminated, it's not easy to determine the presence and degree of infection. On the other hand, multiple organisms are often involved in burn wound infections, and it is not difficult to find two or more bacteria associated with septicemia or other types of invasive infection. It therefore becomes essential to control infection in high-risk patients $^{910}$.

It is estimated that 80 percent of wounds are colonized by microorganisms from the patient's own gastrointestinal and respiratory tracts. The remaining 20 percent are colonized by cross contamination. In both groups, half of the cases result in sepsis ${ }^{13}$.

In the 50's and 60's the increasing amount of antibiotic - resistant bacteria became an additional problemto burned patients. Thus, resistence of Gram negative and Gram positive bacteria in one patient might cause serious consequences for other patients in a same burns unit. This should therefore influence the selection of antibiotics for the treatment of suspected sepsis in these other patients.

In the pre-antibiotic era (1920-1950), 
Silva SLNV, Macedo OG, Damasceno CAV, Carvalho MAR, Cisalpino EO. Bacteriological evaluation of wounds in seriously burned hospitalized patients. Revista da Sociedade Brasileira de Medicina Tropical 24:163-168, julset, 1991

streptococci and staphylococci were becoming prominent microorganisms in burn wound infection, along with Gram negative aerobic rods. After penicillin was discovered, during the 1950's, S. aureus become predominant. By the early 1960 's, $P$. aeruginosa outnumbered $S$. aureus, followed by other Gram negative and facultative rods. Since the 1960's Candida albicans, Candida sp and other fungi have appeared with increasing frequency. Further the oportunistic viruses (CMV, Herpes) have become noteworthy in the 1980 ' $\mathrm{s}^{1419}$. While resistant Gram negative organisms clearly became clinically important in the 1970's, the resistant Gram positive cocci became more frequent in the 1980's. This also occured in the burns unit ${ }^{923}$.

Thus, in the antibiotic era,bacterial resistance has become a factor. The changing bacterial patterns in burn wounds infections are secondary to the recurrent use of both topical and systemic antimicrobial agents. In other words, changing bacterial patterns often reflect changing methods of therapy, more than any other factor. This is specially affected by the method of drug utiliazation $^{81425}$.

The purpose of this paper is to present microbiological data which help develop both effective prophylactic and active infection control programmes for hospitalized burned patients.

\section{MATERIAL AND METHODS}

Patients with serious burns were selected according to extent of area injury and depth ${ }^{21}{ }^{24}$. The age range consisted of adults and children of both sexes. The majority of burns was due to accidents with alcohol, combustible and fireworks, or suicide and homicide.

During the period between May and December 1988, 21 patients were studied bacteriologically at Hospital João XXIII's burn's unit which belongs to "Fundação Hospitalar do Estado de Minas Gerais" in Belo Horizonte, Brazil. Environment specimens of six differenrt sources in the same unit were also studied.

The $\mathrm{CFU} / \mathrm{cm}^{2}$ of skin was evaluated according to Williams et $\mathrm{al}^{26}$ in 1984 , by innoculation of one standard filter paper disc, which was used to collect specimens, in a $10 \mathrm{ml}$ thioglycollate broth. Successive dilutions up to 10 ${ }^{10}$, after homogenization in mechanic shaker (Vortex), were then perfomed. From previously established dilution, $0.03 \mathrm{ml}$ doubled volumes were subcultured in blood agar plates. After $24 \mathrm{~h}$ of incubation at $30^{\circ} \mathrm{C}$ and $37^{\circ} \mathrm{C}$, the colony count was made ${ }^{26}$.

The isolated colonies were subcultured in brain heart infusion broth to get pure culture. The tests for presumptive identification were made according to what is precognized for each group of bacteria $^{251218}$.

Susceptibility profiles of isolates were determined following Bauer - Kirby disk agar diffusion method ${ }^{3}$, using properly selected antibiotic ${ }^{12}$, including those used in the hospital. Strains of reference were used as control: Klebsiella pneumoniae ATCC 27736 and Staphylococcus aureus ATCC 25923.

\section{RESULTS}

The most common organisms recovered from wounds of patients were: Pseudomonas aeruginosa, Staphylococcus aureus and Staphylococcus epidermidis (Table 1). P. pseudomallei was the most frequent strain recovered from environmental specimens (Table 2). In nearly all patients specimens ( 16 in total) from whom $P$. aeruginosa was isolated, the rate of $\mathrm{CFU} / \mathrm{cm}^{2}$ of skin was above $10^{2}$. In nine of these, it reached $10^{5}$.

Table 1 - Bacterial organisms isolated from burn wounds of child and adult patients during the period studied.

\begin{tabular}{lr}
\hline Orgamisms & $\begin{array}{c}N^{\circ} \text { of } \\
\text { patient }\end{array}$ \\
\hline Gram negative aerobic an facultative bacteria & \\
Pseudomonas aeruginosa & 16 \\
Pseudomonas sp & 2 \\
Klebsiella sp & 2 \\
Proteus sp & 1 \\
Citrobacter sp & 2 \\
Escherichia coli & 1 \\
Acinetobacter calcoaceticus subsp. anitratus & \\
& \\
Gram positive aerobic and facultative bacteria & \\
Staphylococcus aureus & 5 \\
Staphylococcus epidermidis & 2 \\
Enterococcus faecalis &
\end{tabular}


Silva SLNV, Macedo OG, Damasceno CAV, Carvalho MAR, Cisalpino EO. Bacteriological evaluation of wounds in seriously burned hospitalized patients. Revista da Sociedade Brasileira de Medicina Tropical 24:163-168, julset, 1991

Table 2 - Bacterial organisms isolated from 3 of 6 distinct environment specimens (soap, floor, shower hose).

Organisms $\begin{gathered}\mathrm{N}^{\circ} \text { of } \\ \text { isolations }\end{gathered}$

Pseudomonas pseudomallei

Acinetobacter calcoaceticus subsp lwoffi

Enterobacter $s p$

Antimicrobial susceptibility tests showed multiple drug resistence $(\mathrm{MDR}=$ resistent to at least two aminoglycosides, amplicillin and first generation cephalosporins $s^{9}$ ) in 87 percent of $P$. aeruginosa strains isolated from burn - wounds (Table 3). P. pseudomallei strains recovered from environmental specimens (soap, floor and shower hose) were sensitive to aminoglycosides; moderately sensitive to cefotaxime and resistent to all other tested antibiotics.

\section{DISCUSSION}

It is accepted that the number of $10^{3}$ bacteria $/ \mathrm{cm}^{2}$ of skin in burned patients, equivalent to $10^{5} \mathrm{bacteria} / \mathrm{g}$ of burned tissue, is indicative of impending sepsis for aerobic and facultive bacteria ${ }^{26}$. Other reports suggest that there is critical number of bacteria, between $10^{4}$ and $10^{6}$ organisms/ $\mathrm{g}$ of burned tissue ${ }^{10}$. This figure is compatible with the existence of category intermediate between colonization and invasion ${ }^{11}$ which would correspond to $10^{2}-10^{4}$ microorganisms $/ \mathrm{cm}^{2}$ of skin, with the disc techique used in this work. Reports of $10^{3}$ $\mathrm{CFU} / \mathrm{cm}^{2}$ of skin, (Witch would be equivalent to $10^{5}$ organisms per gram of tissue), are compatible with, but not diagnostic of, burn wound infection ${ }^{1}$ ${ }^{1020}$. Though less diagnostic, surface cultures do give information which is useful for surveillance and epidemiologic control'.

In nearly all patient specimens from which $P$. aeruginosa (16 patients; Table 1) was isolated, the rate of $\mathrm{CFU} / \mathrm{cm}^{2}$ of skin was above $10^{2}$. In 9 of these, it reached $10^{5}$, which is equivalent to $10^{7}$

Table 3 - In vitro antimicrobial susceptility of $\mathrm{P}$. aeruginosa strains isolated from burn - wounds as determined by Kirby - Bauer disc diffusion.

\begin{tabular}{|c|c|c|c|c|c|c|c|c|c|c|c|c|c|c|c|c|}
\hline \multirow{2}{*}{ Antimicrobial drugs } & \multicolumn{16}{|c|}{ Patient strains } \\
\hline & $: 1$ & 2 & 3 & 4 & 5 & 6 & 7 & 8 & 9 & 10 & 11 & 12. & 13 & 14 & 15 & 16 \\
\hline Ąmikacin & $\mathrm{S}$ & $\mathbf{R}$ & $\mathrm{R}$ & $\mathrm{R}$ & $\mathrm{R}$ & $\mathrm{R}$ & $R$ & $\mathrm{~S}$ & $\mathrm{~S}$ & $\mathrm{~S}$ & $R$ & $\mathrm{R}$ & $\mathbf{R}$ & $\mathrm{R}$ & $R$ & $\mathrm{R}$ \\
\hline Amoxicillin & $\mathrm{R}$ & $\mathbf{R}$ & $\mathrm{R}$ & $R$ & $\mathrm{R}$ & $\mathbf{R}$ & $\mathrm{R}$ & $\mathrm{R}$ & $\mathrm{R}$ & $R$ & $\mathrm{R}$ & $R$ & $R$ & $\mathrm{R}$ & $R$ & $\mathbf{R}$ \\
\hline Ampicillin & $\mathrm{R}$ & $\mathrm{R}$ & $R$ & $\mathrm{R}$ & $\mathrm{R}$ & $\mathrm{R}$ & $\mathrm{R}$ & $\mathrm{R}$ & $\mathrm{R}$ & $\mathrm{R}$ & $\mathbf{R}$ & $R$ & $\mathrm{R}$ & $\mathrm{R}$ & $\mathbf{R}$ & $\mathrm{R}$ \\
\hline Carbenicillin & $\mathrm{R}$ & $\mathrm{R}$ & $\mathrm{R}$ & $\mathrm{R}$ & $\mathrm{R}$ & $\mathrm{R}$ & $\mathrm{R}$ & $\mathrm{S}$ & $\mathrm{S}$ & $\mathrm{S}$ & $R$ & $\mathrm{R}$ & $\mathrm{R}$ & $\mathrm{R}$ & $\mathrm{R}$ & $\mathrm{R}$ \\
\hline Cefotaxime & $\mathrm{R}$ & MS & MS & $R$ & $\mathrm{R}$ & MS & $\mathrm{R}$ & MS & MS & MS & $\mathrm{R}$ & MS & $R$ & $\mathrm{R}$ & MS & $R$ \\
\hline Cephaloridine & $\mathrm{R}$ & $\mathrm{R}$ & $\mathrm{R}$ & $\mathbf{R}$ & $\mathrm{R}$ & $\mathrm{R}$ & $R$ & $\mathrm{R}$ & $\mathrm{R}$ & $\mathrm{R}$ & $\mathbf{R}$ & $\mathrm{R}$ & $R$ & $\mathrm{R}$ & $\mathrm{R}$ & $R$ \\
\hline Cephatothin & $\mathrm{R}$ & $R$ & $\mathrm{R}$ & $\mathrm{R}$ & $R$ & $\mathrm{R}$ & $\mathrm{R}$ & $\mathrm{R}$ & $\mathrm{R}$ & $\mathrm{R}$ & $\mathrm{R}$ & $\mathrm{R}$ & $\mathbf{R}$ & $R$ & $R$ & $\mathbf{R}$ \\
\hline Chloramphenicol & $\mathrm{R}$ & $\mathbf{R}$ & $\mathrm{R}$ & $\mathrm{R}$ & $\mathbf{R}$ & $\mathrm{R}$ & $\mathrm{R}$ & $\mathbf{R}$ & $\mathrm{R}$ & $\mathrm{R}$ & $\mathbf{R}$ & $\mathrm{R}$ & $\mathrm{R}$ & $\mathbf{R}$ & $R$ & $\mathbf{R}$ \\
\hline Gentamicin & $\mathrm{R}$ & $\mathbf{R}$ & $\mathrm{R}$ & $\mathrm{R}$ & $\mathbf{R}$ & $\mathrm{R}$ & $\mathbf{R}$ & $\mathrm{S}$ & $\mathrm{S}$ & $\mathrm{S}$ & $\mathrm{R}$ & $\mathrm{R}$ & $\mathrm{R}$ & $\mathrm{R}$ & $R$ & $\mathbf{R}$ \\
\hline Kanamycin & $\mathrm{R}$ & $\mathbf{R}$ & $\mathrm{R}$ & $\mathrm{R}$ & $\mathbf{R}$ & $\mathrm{R}$ & $\mathrm{R}$ & $\mathbf{R}$ & $\mathrm{R}$ & $\mathrm{R}$ & $\mathrm{R}$ & $\mathrm{R}$ & R & $\mathrm{R}$ & $R$ & $\mathrm{R}$ \\
\hline Penicillin G & $\mathrm{R}$ & $\mathrm{R}$ & $\mathbf{R}$ & $\mathbf{R}$ & $\mathrm{R}$ & $\mathrm{R}$ & $\mathrm{R}$ & $\mathrm{R}$ & $\mathrm{R}$ & $\mathrm{R}$ & $\mathrm{R}$ & $R$ & $R$ & $\mathrm{R}$ & $R$ & R \\
\hline Tetracycline & $R$ & $\mathrm{R}$ & $\mathrm{R}$ & $\mathrm{R}$ & $\mathbf{R}$ & $R$ & $\mathbf{R}$ & $\mathrm{R}$ & $R$ & $R$ & $\mathrm{R}$ & $R$ & $R$ & $\mathrm{R}$ & $R$ & $\mathrm{R}$ \\
\hline $\begin{array}{l}\text { Trimethoprin- } \\
\text { sulfamethoxazole }\end{array}$ & $\mathrm{R}$ & $R$ & $\mathrm{R}$ & $R$ & $R$ & $\mathrm{R}$ & $R$ & $\mathbf{R}$ & $\mathrm{R}$ & $\mathrm{R}$ & $R$ & $R$ & $\mathrm{R}$ & $R$ & $\mathbf{R}$ & $\mathrm{R}$ \\
\hline
\end{tabular}

$\mathrm{S}=$ susceptible; $\mathrm{MS}=$ moderately susceptible; $\mathrm{R}=$ resistant 

set, 1991

$\mathrm{CFU} / \mathrm{g}$ of burned tissue. The high $\mathrm{CFU} / \mathrm{cm}^{2}$ rates found in nearly half of the patients examined are also important when one takes into consideration the high level of susceptibility of burned patients, and the potencial source of cross - contamination (as observed by MacMillan et al ${ }^{14}$ in 1986).

It's thought that from the time of burn injury the infection of wound follows a set sequence, with respect to aetiological agent and the duration of infection. Firstly, it is invaded by Streptococcus sp and Staphylococcus aureus; followed a few days later by Gram-negative rods, which are future pathogens. At end of this process, after the patient has been furnished with broaspectrum antibiotics, the fungi appear ${ }^{17}$. According to information available, in the majority of burn infections one strain of Gram negative bacteria (Pseudomonas sp) predominates. However, a great number of other organisms have been replacing $P$. aeruginos $a$ in importance ${ }^{1315}$. The present results show that in Brazil, $P$. aeruginosa still requires special care for its control, for it is still the most frequent organism, occurring in approximately 75 per cent of patients.

The great majority of these microorganisms were shown to be resistant to all antibiotics tested. According to Muir et all ${ }^{16}$ in 1987, 30 per cent of burned patients develop $P$. aeruginosa infection, but, in recent years, only 5 per cent of pacients have been given antipseudomona antibiotes (aminoglycosides). A rational and firmly enforced antibiotic policy is essential, both for the management of the individual patient and to prevent the development of antibiotic - resistant strains of organisms in the ward environment.

Studies about epidemiology and control of multiresistant strains, have shown that aminoglycoside resistence has occurred with higher frequency in isolates of wounds and sputum, which usually have poor penetration. It's thought therefore, that the presence of sub inhibitory levels of drugs in these situations contributes to the production of multiresistant strains. The resistance of the isolates to aminoglycosides has been also related to inadequade dosage ${ }^{25}$. However, there is some controversy as to the relation between amikacin use and resistance, as some hospitals have used amikacin extensively, without noticing any increase in resistance. Therefore, the incidence depends, in any situation, on the prevalence of the various inativating amikacin enzimes in organisms of the hospital, as well as on adequate aminoglycosides dosing ${ }^{72}$.

Pseudomonas pseudomallei isolated from environment spcimens showed a different susceptibility from those of $P$. aeruginosa isolated from patients. These $P$. pseudomallei invariably shown to be sensitive to amikacin, gentamicin, and kanamycin; moderately sensitive to cefotaxime and resistant to all other tested antibiotics.

The sepsis prevention in wound burns depend on maintenance of a low concentration of bacteria in the injury ${ }^{42}$. A wide variety of topical agents are available to inhibit the bacterial growth in burns but no one has fulfilled all the requirements for an ideal topical agent $t^{91623}$. With the extended use of any of these agents (silver nitrate, $0.5 \%$. silversulfadiazine, mafemide of sodium, povidoneiodine), resistant organisms inevitably appear.

The use of topic antibiotic agents has decreased mortality among patients with less than $40 \%$ of corporal area burned. In most of the burned patients centers, topic agents are now used in association with debridement or surgical excision for serious injury ${ }^{1314}$.

A fundamental aspect to be considered is the situation of the Antibiotic subject in medical courses, at the moment included as a small topic. The little time devoted to this matter is a consequence of the subject not being considered as a speciality. Thus, no other group of drugs has such a remarkable effect in the community as a result of its misuse in terms of both cost and increased bacterial resistance ${ }^{\mathrm{g}}$.

Antibiotic proliferation, the availability of other drugs and the existence of several different sources of information about drugs, has made it difficult to secure rational orientation and controlled prescription. However efforts must be made in this direction, mainly by Infection Control Comissions.

Additional studies, correctly structured, in the field of microbiology, in different centers for burned patients are therefore necessary in Brazil. With the microbiologic data from the data 
Silva SLNV, Macedo OG, Damasceno CAV, Carvalho MAR, Cisalpino EO. Bacteriological evaluation of wounds in seriousty burned hospitalized patients. Revista da Sociedade Brasileira de Medicina Tropical 24:163-168, julset, 1991

obtained, it will be possible to provide better infection control to the burned patient.

\section{RESUMO}

No período de maio a dezembro de 1988 , foram avaliados bacteriologicamente 21 pacientes da Unidade de Queimados do Hospital Joāo XXIII pertencente à Fundação Hospitalar do Estado de Minas Gerais, em Belo Horizonte, Brasil. A avaliação qualitativa e quantitativa de bactérias aeróbicas e facultativas de queimaduras foi realizada através da técnica do disco de papel de filtro padronizado, incluindo a susceptibilidade a antimicrobianos. Ao mesmo tempo, foi realizada uma avaliação das bactérias isoladas do ambiente da Unidade. Os microrganismos mais frequentemente recuperados das feridas dos pacientes foram: Pseudomonas aeruginosa, Staphylococcus aureus, Staphylococcus epidermidis. A espécie $P$. pseudomallei foi a mais frequente nos espécimes ambientais. Em quase todos os espécimes de pacientes dos quais $P$. aeruginosa (16 pacientes) foi isolada, a taxa $\mathrm{CFU} / \mathrm{cm}^{2}$ de pele estava acima de $10^{2}$. Em nove destes, alcançou $10^{5}$, o que equivale a $10^{7} \mathrm{CFU} / \mathrm{g}$ de tecido queimado.

Palavras-chaves: Infecçāo hospitalar. Infecção de queimaduras.

\section{ACKNOWLEDGMENTS}

The authors are indebted to Dr. Nelson Luis Figueiredo Caescaes for his cooperation, helpful suggestions and critical reading the manuscript and Luzia Rosa Resende for the technical help. The authors wish to thank the staffs of Burn Unit of Hospital João XXIII for their excellent cooperation.

\section{REFERENCES}

1. Achauer MB. Treating the burn wound. In: Management of the Burned Patients. Appleton \& Lange. Norwalk p.93-107, 1987.

2. Ballows A, Hausler Jr WJ. Diagnostic procedures for bacterial, mycotic and parasitic infections. American Pulic Healthy. Association Inc Washington, 1981.

3. Bauer AW, Kirby WMM, Sherris JC, Turck M. Antibiotic susceptibility testing by a standardized single dise method. American Journal of Clinical Pathology 45: 493-496, 1966.
4. Brook I, Randolph JG. Aerobic and anaerobic bacterial flora or burns in children. Journal of Trauma 21: 313-318, 1981.

5. Cowan ST, Steel's KJ. Manual for identification of medical Bacteria. 2nd edition, University Press, London, Cambridge, 1973.

6. Echinard CE. Immunit of the burned patient. Scandinavian Journal of Plastic And Reconstructive Surgery And Hand Surgery 21: 317-321, 1987.

7. Eickhoff T. Antibiotics and nosocomial infections. In: Bennett JV, Brachman PS(eds) Hospital Infections, 2nd edition, Little Brown, Boston p.171192,1986

8. Gould IM. Control of antibiotic use in the United Kingdon. Journal of Antimicrobial Chemotherapy 22: 395-397, 1988.

9. Hansbrough JF, Carroll WB, Zapata-Sirvent RL, Reller BR, Boswick JA. Identification and antibiotic susceptibility of bacteria isolates from burned patients. Burns, Including Thermal Injury 11: 393-403, 1985.

10. Heggers JP, Robson MC. Infection control in burn patients. Clinics in Plastic Surgery 13: 39-47, 1986.

11. Kagan RJ, Matsuda T, Hanumadass M, Jonasson $O$. Serious wounds infections in burned patients. Surgery 98: 640-649, 1985

12. Lennette EH, Balows A, Hausler Jr WJ, Shadomy HJ. Manual of clinical microbiology. American Society for Microbiology, Washington, 1985

13. Luterman A, Dacso CC, Curreri PW. Infections in burn patirents. American Journal of Medicine 81 (Suppl 1A): 45-52, 1986.

14. MacMillan BG, Holder IA, Alexander JW. Infections of burn wounds. In: Bennett JV, Brachman PS (eds) Hospital Infections, 2nd edition, Little Brow and Company, Boston p.465-482, 1986.

15. McManus WF, Goodwin CW, Mason AD, Pruitt Jr BA. Burn wound infection. Journal of Trauma 21:753-756, 1981.

16. Muir IIK, Barclay TL, Settle JAD. Local treatment of the burn wound. In: Burns and their treatment, 3rd edition Butterworths, London p.55-112, 1987.

17. Murray PM, Finegold SM. Anaerobes in burnwound infections. Reviews Infection Diseases 6 (suppl 1): S184-S186, 1984.

18. Pessoa GVA, Silva EAM. Meios de Rugai e Lisina-motilidade combinados em um só tubo para a identificação presuntiva de enterobactérias. Revista do Instituto Adolpho Lutz 32: 97-100, 1972.

19. Pruitt Jr BA. Infections caused by Pseudomonas species in patients with burns and in other surgical patients. The Journal Infections Diseases 130 (suppl): S8-S13, 1974. 
Silva SLNV, Macedo OG, Damasceno CAV, Carvalho MAR, Cisalpino EO. Bacteriological evaluation of wounds in seriously burned hospitalized patients. Revista da Sociedade Brasileira de Medicina Tropical 24:163-168, julset, 1991

20. Pruitt JR BA, McManus AT. Opportunistic infections in severely burned patients. The American Journal Medicine 76: 146-154, 1984.

21. Robertson KE, Cross PJ, Terry JC. The crucial first days. AmericanJournal Nursery 85: 30-45, 1985.

22. Russo AC. Queimaduras "Acidentes de Trabalho" (subsídios à sua prevenção). Jornal Brasileiro de Medicina 44: 27-35, 1983.

23. Stanford W, Rappole BW, Fox CL. Clinical experience with silver sulfadiazine, a new topical agent for control of Pseudomonas infections in burns. Journal of Trauma 9: 377-388, 1969.
24. Sucena RC. Fisiopatologia e tratamento das queimaduras. Livraria Roca, São Paulo, 1982.

25. Weinstein RA. Multiply resistant strains: epidemiology and control. In: Bennett JV, Brachaman PS (eds) Hospital Infections, 2nd edition. Little Brown, Boston p. 151-169, 1986.

26. Williams HB, Breidenbach WC, Callaghan WB, Richards GK. Prentis JJ. Are burn wound biopsies obsolete? A comparative study of bacterial quantitation in burn patients using the absorvent disc and biopsy techniques. Annals of Plastic Surgery 13: 388-395, 1984. 